\title{
What happened to the world's money?
}

Disappointment among financiers about the slow pace of the West's recovery from recession is understandable, but they should not be so surprised; who but they are helping to reinvest the world's capital internationally?

THE past few months have had the world's financiers gnashing their teeth, and for good reason. Their worry seems to be that the rules of the game they have been playing profitably for several decades seem to have changed. The recession that began in 1991 appears to be ending, but not according to the book. Both in Britain and the United States, for example, output appears to have reached a minimum a year ago, but since then its growth has been much slower than had been expected. The classical function of a recession, which is to impose such financial strains on economically marginal enterprises that they go bankrupt, appears to have worked all too efficiently; the bankruptcy courts have been thronged for a long time now. But the ending of the recession has not this time seemed like the liberation of productive enterprises, made lean and efficient during recession, from the financial restraints of high interest rates. What has gone wrong?

For one thing, although enterprises that managed to survive the recession may now be more efficient, they are often embedded in economies not in spectacularly good shape. The US federal deficit is still with us, but now the British government (which is running up debts at the rate of $£ 50$ billion a year), has one of proportionately comparable magnitude and can boast of a $£ 20$ billion annual trade deficit as well. Similarly, Germany's structural problems persist, with the cost of modernizing the eastern Länder not covered by commercial investment having to be financed by further public borrowing. Governments everywhere appear to be in deficit.

But will not those problems melt away when economic activity picks up elsewhere, as it has recently shown signs of doing in both France and Japan? Then, the conventional wisdom has it, the demand for internationally traded goods will revive so that trade balances correct themselves, while more people will find jobs to do so that governments' tax revenues will increase and fiscal deficits will disappear at the same time. Would that it were that simple!

One of the rules of the game that have changed, probably for ever, is the scale on which funds are now invested across national frontiers. In the old days, when a successful business decided what to do with its surplus funds, it would usually invest them in its existing operation, making it larger or otherwise more productive. Now it is often easier, and potentially more profitable, to extend elsewhere or to buy a related business somewhere else (as the German car maker BMW bought British Rover Cars the other day). Emergent economies such as China are a powerful attractor for such funds. So, on a smaller scale, are the countries of Central Europe and Central and Latin America. The total amount of direct investment in emergent economies may now be comparable with the US federal deficit, say $\$ 250$ million-plus a year. In the old days, of course, the same funds would have stayed where they were generated, improving the productive capacity of those who earned them. That is part of the real reason why the recovery from the recession is so slow.

But these are not the only overseas investments the prosperous world should now be making. Continuing confusion over the future of Russia is a reminder that the industrialized West never made good its promises to provide financial assistance for the reconstruction of the Russian economy. Instead, there is an emerging argument about the reasons for the growth of reactionary forces there. It is even more urgent that the West should take a decisive lead in reinvigorating the developing world, but that cause is also on the back burner, pending the awaited return of prosperity.

But what if the rules have really changed, and if prosperity 1980 s-style does not float back with the return of spring in the Northern Hemisphere? The best bet is that private capital (mostly owned by the West's contributors to pension schemes and other savings schemes) will continue to follow commercial opportunities, while governments' obligations to others less fortunate will take up a substantial part of whatever extra wealth is generated. The view that that is what should happen cannot easily be denied, given the political dangers of continued neglect. That is why this recession will not end with a joyous bang, but with a long drawn-out whimper. $\square$

\section{Small country research}

The European Union should pay attention to the research needs of smaller countries.

QUEBEC and Wales (part of the United Kingdom) have more in common than a language of their own. Quebec, with fewer than 7 million people, is a striking example of a small community seeking to make its way in the world by research; its provincial government has managed to find the resources usefully to complement those available federally, but there is some way to go (see page 389). Wales, with 4 million people, is a less autonomous part of the United Kingdom, but appears to share Quebec's belief of a quarter of a century ago that it is neglected by the central government in research 